\title{
Social Wellbeing and Collective Happiness (Study of "Sedekah Selamatan Sîr" on Career Development)
}

\author{
Samsul Arifin ${ }^{1}$, Akhmad Zaini $^{2}$ \\ \{email syamsulahasan@ibrahimy.ac.id ${ }^{1}$, konseling.attawazun@ gmail.com ${ }^{2}$ \} \\ Universitas Ibrahimy, Situbondo, Indonesia ${ }^{1,2}$
}

\begin{abstract}
Ulama from the Besuki Residency (Situbondo, Bondowoso, Banyuwangi, and Jember) in the past, had local wisdom in carrying out harmony, happiness and social resilience through philanthropy in the form of alms salvation. Among them is alms salvation called "Sedekah Selamatan Sîr" which is done by people who feel successful in their work or so that they grow in their careers. The purpose of this study is to understand the meaning of "Sedekah Selamatan Sîr" and its implementation of career development. This research uses ethnographic methods. The results of this study indicate that "Sedekah Selamatan Sîr" means as a reminder that careers must contain worship values, expect blessings for families, and give alms to maintain harmony with neighbors. Career choice and development is the process of developing self-concept; quality and self-competence and pay attention to the environmental context. People are considered successful in their careers if they do not just feel prosperous and happy collectively with their family, friends
\end{abstract}

Keywords: Selamatan Sîr, self-concept, career.

\section{Introduction}

In the era of economic globalization and disruption, almost all individuals were overwhelmed with worries about their careers. Some issues about careers that worry people in various countries, among others: the search for life purposes and meanings, the journey in actualizing themselves through various life-related life roles, and the efforts of the state in overcoming employment and unemployment [1]. Even according to a survey of the CSIS in 2017, the problem most experienced by millennials in Indonesia is ranked first (25.5\%), namely limited employment. But even so, career and employment problems rank $3(7.5 \%)$ as a source of happiness; still inferior to health, which is $40 \%$ and enjoy free time with family, $26.8 \%$ [2].

Career is a manifestation of a person's life and meaningful life. This meaningfulness is because careers include life roles, life settings, and life events. Career choice and development - according to self-concept theory-is the process of developing and applying one's selfconcept. This self-concept is the result of a dynamic interaction of one's personality quality and competence with others and the environment [1].

Self-concept theory in career development that relates to social context is very interesting when we connect with our culture that emphasizes collectivity and togetherness with others. In our culture, if a person is successful in a career, he or she holds selamatan-or at a minimum - treats their friends' banquets. This selamatan, for religious people, is not only worthy of worship but also as a donation, sharing fortune with neighbors and colleagues. Self- 
perception of career success does not only concern yourself but also perceived success by others.

A selamatan event organized by the residents of the Besuki Residency (Situbondo, Bondowoso, Banyuwangi, and Jember) related to careers, such as "Selamatan Assir Jailani " or popularly abbreviated as "Sedekah Selamatan Sîr". This selamatan is held by someone, if he gets a gift in his career or so that his career continues to grow. He invited a number of friends and neighbors to prayer and banquet together. "Selamatan Sîr" means a reminder that careers must contain worship values, expect blessings for the family, and give alms to neighbors. Thus, a career must be good before God, good in front of the family, and also good in the perception of others. Careers must bring collective prosperity and happiness.

This "Sedekah Selamatan Sîr" is the local wisdom of the residents of the Besuki Residency in maintaining and developing their careers. In the perspective of counseling, this salvation can be used as a technique to turn someone into a good person. Because counseling is a service that helps people to overcome life's problems and accelerate their potential to growth and development for the better [3]-[5]. Career counseling, counseling related to a person's life journey related to efforts to earn a living to fulfill their daily lives.

Selamatan in the tradition of the Madurese people, many kinds. Nurwidodo (2006), who examined traditional health in Madura, concluded the ritual of Selamatan Rokat for the Madurese community as an effort to prevent illness. Another Selamatan is Selamatan Kadiran, which is the popular attendance at Sumenep [6], [7].

From some research on selamatan that took place in Madura, to the best of the researchers' knowledge, none has been linked to career counseling. Some research in Indonesia that connects with careers is mostly research on cultural values. For example, Istiqomah who examines the values of work in Fiber Wedhatama (inter alia, religious, cautious, humble, and responsible) can be used as character building counselees to have a positive Java-based work culture that can be integrated with career counseling services [8]. Another study, conducted by Muslihati who examined the Minang and Madura cultural values regarding psychological well-being. In the view of these two cultures, people will achieve prosperity if they can manage relationships with God and others. People will be considered prosperous if they can meet basic needs, have financial independence, and health [9].

This research, will focus on the meaning of "Selamatan Sîr" and its implementation on career development, especially in the perspective of self-concept theory of career development.

\section{Method}

This paper uses the ethnographic method. Because this research reveals and describes the patterns, typologies, and cultural categories of a community. Ethnography means learning from the community through cultural behavior, cultural knowledge, and cultural artifacts from their perspective [10]-[13]. The researcher acts as a research instrument as well as a data collector. Researchers also do full participation. Sources of data in this study: first, documents (especially the Al-Adzkârul Yaumiyah, Jâmi'ud Da'awât, and Risâlatut Tadzkirah fi Aqdin Nikâh). This written document is very important because if we want to know a local tradition we must do an analysis of customs, ritual worship, and knowledge of those who are also contained in the textual tradition or religious books [5], [14], [15]. Other data sources are observation fields and in-depth interviews.. Some of the data is netted by key informant 
techniques and purposive sampling techniques. The steps of data analysis can be simplified into three activities that occur simultaneously, namely data reduction, data display, and conclusion drawing.

\section{Results and Discussion}

"Sîr" is a popular selamatan among the residents of the Besuki Residency, especially alumni of Pondok Pesantren Salafiyah Syafi'iyah Sukorejo Situbondo. Even this selamatan, also pupuler in Madura with the name "Selamatan Kadiran or Tarekat Kadiran" which was first brought by Shaykh Abu Bakar or Kiai Syahruddin. Kiai Syahruddin is one of students K.H.R As'ad Syamsul Arifin, Salafiyah Syafi'iyah Syafi'iyah Sukorejo Situbondo [6], [7], [16]

Researchers find it difficult to trace the origin of "Selamatan Sîr". Some informants explained that this tradition originated from the K.H.R Syamsul Arifin, founder of the Pondok Pesantren Salafiyah Syafi'iyah Islamic Sukorejo Situbondo. Researchers found that two books containing the text "Assîr Jailani" or "Sîr": "Al-Adzkârul Yaumiyah" by K.H.R. Achmad Fawaid As'ad and "Jâmi'ud Da'awât", by Ustadz Sukaryo. Both books are very popular among the Besuki and Sukorejo santri people who are spread throughout the archipelago [17], [18].

"Selamatan Sîr" is usually held at night. After the Isha prayer, the host prepares certain foodstuffs to be cooked together. The host invited several neighbors and colleagues. The material provided for the Selamatan Sîr, among others: first, rice as much as 2 fitrah $(5 \mathrm{~kg})$ or enough, depending on the number of invitation participants of the selamatan. Second, rice pocong, made from glutinous rice, as many as seven pieces. Third, roosters, the amount depends on the number of participants' selamatan. Fourth, salabed money is 7 dirhams (Rp. 750). Fifth, curry seasoning for chicken side dishes. The process of cooking the banquet, until midnight [19], [20].

After cooking, continue with the prayer program together. The participants in a holy state, sat cross-legged while forming a circle. an imam leads tawassul recitation to 1) Prophet Muhammad, the prophet's family, the companions of the prophet, and the prophets; 2) the Muslims and Muslims; and 3) to Shaykh Abdul Qodir Jailany.

After that, read the seven surah of the al-Qur'an selected. These seven letters, were read by the participants of the salvation, according to the part that had been determined by the priest. The seven letters, among others: QS. Yâsin (3x), QS. al-Wâqiah (3x), QS. az-Zalzalah (3x), QS. as-Shams, QS. ad-Dhuhâ, QS. al-Insyirâh, QS. al-Ikhlâs (11x),

After that, the imam together with the participants of the salvation read the Qur'an, shalawatan, asmaul husna, namely: QS. al-Ikhlâs, QS. al-Alâq, QS. an-Nâs, QS. al-Baqarah 15, Ayat Kursi, QS. al-Baqarah 284-286, Allahumma shalli wa sallim 'alâ Sayyidina Muhammad wa 'alâ âli Sayyidina Muhammad (100x), As-sholâtu was salâmu 'alaika yâ Rasulallâh (100x), Yâ hâdi yâ 'alîm yâ khabîr yâ mubîn (100 x) Then the priest reads the prayer.

Some of the Surahs of the Qur'an which are read in the Selamatan Sir, contains hope for those who hold the Sîr, as contained in these letters, namely: first, the QS. Al Fatihah. This letter is called Al-Fatihah because it is a very great opening for all virtues. The Surah AlFihtah is also called asy-syâfiyah (the healer), al-kâfiyah (which suffices), al-wâqiyah (which protects), and ar-ruqyah (the mantra). Because this surah can cure all kinds of diseases, it can suffice humans to overcome all disquiet, can protect humans from all bad, and can function as 
a mantra in the face of adversity. The main purpose and theme of the Surah Al-Fatihah are to create awareness of God's supervision [3], [21], [22].

Second, QS. Yâsin. Surah Yasin is known by the name of the heart of the Qur'an (qalbu al-Qur'an). Surah Yasin is also named after those who reject and support (ad-dafi'ah) and those who stipulate (al-qadhiyah); for whoever believes in the prophetic treatise, that belief will reject all distress, and support and determine for that person various virtues and give him what he expects. One of the privileges of Yasin's surah, for those who read it, will be given abundant convenience when facing difficulties in his life [17], [21], [23].

Third, QS. al-Wâqiah. The theme of surah al-Wâqiah is the description of the Day of Judgment, an explanation of something that will happen on earth, and three categories of people. The first category, al-muqarrabun; those who are brought near are those who have neglected themselves so that all of their activities are due to Allah. Then people who enter this group will get comfort (and peace of all anxiety, sickness, and something that relegates), fortune (grace which bestows and satisfies), and a paradise of pleasure. Second, al-maimanah or al-yamin; the right which implies blessing, kindness, and happiness. This group will get safety and peace. Both of these groups, including the inhabitants of heaven. Third, almasy'amah or ash-syimal; the left is the group whose lives dissipate, arrogantly forget God, and continually commit great sins. This group will go to hell [21], [24], [25].

Fourth, QS. al-Zalzalah. The main theme of Surah al-Zalzalah is the description of Doomsday and what people experienced at that time. At that time, all problems will open up and become apparent what is hidden. Many big events both positive and negative- start from small things; man will see his deeds no matter how small they are. One of the wisdom of reading QS. al-Zalzalah, will not experience a terrible shock and his life is fulfilled [21].

Fifth, QS. al-Shams. The main purpose of Surah al-Shams is the suggestion to do a variety of virtues and avoid some evil. This Surah reminds us, the happiness of human beings - who know piety and lawlessness based on the knowledge God has made to Him-is to purify and develop themselves with good development and decorate it with piety and avoid it from all iniquity. Conversely, failure to achieve success is by harboring that positive potential [5], [21].

Sixth, QS. al-Dhuhâ. The main theme of this surah is the refutation of the allegation stating that Allah has left the Prophet Muhammad, due to the length of time the Prophet did not receive revelation while entertaining the Prophet with the acquisition of God's grace. These gifts: first, the Prophet Muhammad was orphaned and then he was given protection so that he was demanded not to act arbitrarily with orphans. Second, the Prophet Muhammad was in a state of need, inadequate and then obtained sufficiency and satisfaction; as a sign of gratitude, the Prophet Muhammad was instructed not to refuse let alone rebuke anyone who asks or asks. Third, the Prophet Muhammad was confused and did not know the right direction then he got religious instructions; so he is obliged to convey some of these instructions to others [17], [21], [26].

Seventh, QS. al-Insyirah. The theme of this surah, the pacification of the Prophet Muhammad SAW concerning the past and future as well as guidance to try hard with optimism [21]. Eighth, QS. al-Ikhlâs. The main theme of Surah Al-Ikhlas is the introduction of God Almighty and who is the mainstay and hope of all beings. The purpose of this surah as an explanation of the Glorious substance (Allah) and His fairness bear the pinnacle of all perfect attributes and avoids from Him all deficiencies [21], [23]. Ninth, QS. al-Falaq and QS. anNâs. These two surah are also called al-mu'awwidzatain,, which are two surah that guide the reader to the sanctuary or put it in a protected arena. The theme of this letter, teaching to lean on and ask for protection only from God in the face of all kinds of evil [21], [27]. 
Thus, the reading of the Qur'an which is read in the Selamatan Sir contains elements of hope for happiness (for example optimism, good deeds, peace of all anxiety, illness, and something disturbing), well-being (eg abundant fortune and feeling sufficient) and hope for God's pleasure. The readings in Selamatan Sir are full of Islamic values. Whereas the tradition of feast and banquet food comes from the traditions of the local community. This is similar to the tradition of tahlilan. The tradition of gathering together and food comes from the local community. Then the ulama used to do the Islamization by holding a prayer together.

\subsection{Meaning of Selamatan: Achieving Collective Welfare and Happiness \\ Reminder of worship (ibadah) and the pleasure (ridha) of Allah}

For the residents of the Besuki Residency who conduct the Selamatan Sirr, a career is not a life purpose but a means of worship. Allah gives fortune to the believers, then the believer should provide for his family to worship God. For believers, earning a living for the conditions of life is not for the purpose of life itself. But even so, believers must work hard because God loves his servants who work hard and improve the lives of the world as a provision in the hereafter [28].

In the view of K.H. Afifuddin Muhajir, careers (which included efforts to seek fortune) included worship which became a couple of prayer, jihad, and pilgrimage. Looking for fortune "equal" position with the prayer, jihad, and pilgrimage. For example, we can read in the Qur'an Surah Al Jumuah: 60. In that verse, there is a clear direction, so that everyone who has the ability to work to go back to work, after they pray (Interview with KH. Afifuddin Muhajir, 25 April 2020).

Thus, a career is a work that is worth worship. Because of that, in carrying out one's career, one must uphold the mandate and live it properly. If we want to live in peace, peace, and prosperity, the money for household needs must come from a lawful way, which does not make any difference to himself and others, and does not contain big or small immorality [25], [28]. According to the community observers of the Selamatan Sîr, by holding the event, they are always reminded that careers also include worship. Therefore, they will always be careful, optimistic, and always carry out their careers with halal.

For practitioners of "Selamatan Sîr", "Sîr" activities are activities to remind them that their careers are a means of worshiping and hoping for the pleasure of Allah. So that in carrying out his career, he will always be careful and hold fast the mandate not to violate the commands of Allah. In his career, he not only pursued worldly prosperity but also happiness ukhrawi. Thus, his life will be calm; a happy world and the hereafter. His career success is not just a success in his self-concept, but also success before God by increasing worship, alms, lawfully undergoing a career, and always hoping for the pleasure of Allah

\section{Hope in blessing in fulfilling family livelihoods}

Selamatan Sîr as a tawassul media to Shaykh Abdul Qodir Jailani and expect the intercession of the Prophet Muhammad SAW. The practitioners of "Sîr" believe, with the intercession of the Prophet Muhammad SAW his blessings will be abundant [19], [20].

One of the obligations of men in a household is to make a living for his family. Looking for a living with the intention of worship. Earning a living, whether farming or trading or other work, for the provision of worship. Sakinah households, are households that have feelings of calm, peace, happiness, and prosperity [28]. Sakinah households must meet basic needs, including: First, sandang. Sandang or clothing must be appropriate following Indonesian culture and Islamic teachings and pay attention to the limits of respect for men's and women's 
clothing. Second, food (ma'isyah) which is obtained in a halal manner to create a sense of comfort and freshness, as well as giving rise to a body that is physically and physically healthy and blessed. Third, housing (houses and yards). The house should be able to meet health standards, cause a sense of comfort, a sense of comfort, and a sense of peace. The house should be equipped with a yard planted with valuable flowers, fruits, and plants. Because the house is a place of physical and spiritual rest [25], [28].

According to the observers of Selamatan Sîr, they have a career to fulfill the family's livelihood to reach the sakinah family. For their family and career to be blessed - containing the abundant coffers of prosperity and goodness in the world and the hereafter - they held the Selamatan Sîr. Thus, Selamatan Sîr, means that his career will bless his family so that they feel prosperous and happy. His career success, not just success in his perception, but also success in his family's perception.

\section{Maintain harmony with friends and neighbors}

Selamatan Sîr is a combination of prayer and alms activities. People who are successful in their careers, the most important worship done, besides giving alms, is giving alms. One of the lessons of charity, to maintain harmony with friends and neighbors.

Sakinah households are not just concerned with their families, but they also have to maintain harmony with their neighbors and surrounding communities. If there are social problems, they must be discussed together and the results of the agreement must also be carried out together [28]. At Selamatan Sîr, harmony and harmony between neighbors are shown on the symbol of seven pocong rice made from glutinous rice (beras ketan). For practitioners of Selamatan Sîr, "Sîr" activities are activities to share and maintain harmony with some of their friends and neighbors. His career success, not just success in his perception, but also success in the perception of some friends and neighbors by inviting them to pray and eat together.

Thus, a successful self-concept in a career for the Selamatan Sîr community of practitioners is that the career does not merely apply the quality of his personality traits and competencies, but a career as a practice in worshiping for life in the hereafter. Career is also a means to reach a sakinah family, a household that has a feeling of calm, peace, happiness, and prosperity. Careers must also be able to reach a safe society; because it must maintain harmony and harmony with neighbors and friends.

This study of Selamatan Sir shows that the self-concept for the residents of the Besuki Residency does not merely apply one's self-concept in his character associated with himself and his environment but also that the career contains religious values. The meaning of careers for the practitioners of Selamatan Sir , careers must contain happiness and collective prosperity in the world and the hereafter

In the theory of self-concept in career development argues, choice and self-development is a process of developing and applying one's self-concept. Self-concept is the result of complex interactions among several factors, including physical and mental growth, personal experience, a person's characteristics, and environmental influences. The concept of self is always dynamic and will continue to grow, along with life experiences, work experience, and other life roles. This super emphasis on environmental contexts is increasingly clear on the theory of life-span, life-scape [29]. A person's self-concept varies greatly, depending on the person's culture. From the perspective of interdependent self-theory, a person's career is more meaningful when he is considered as part of a social relationship where the person's behavior is assessed and depends on the person's understanding of the thoughts, feelings, and actions of others in a relationship [30]-[32]. 
In the context of Selamatan Sîr, a person considered successful in a career is not just feeling collective prosperity and happiness with his family, friends, or neighbors, but that career must also be in line with God's pleasure. Therefore, in carrying out a career, do not harm other people and must be taken in a halal way, so that they will get God's approval. In pursuing a career, it must be worth worshiping, hoping for blessing in making a family living, and maintaining harmony with others.

An understanding of local wisdom, especially the Selamatan Sirr, is important to be inspired and integrated by counselors. Because career exploration in adolescence is an important element in adolescent self-concept [33]. In the view of self-concept theory, growth period (from birth to mid-teens) the development of self-concept through identification with important figures in the family. They study behavior related to themselves, social interactions, and other environments. Likewise in the exploration period (mid-teens the too early twenties), they begin to develop self-concepts through role and exploration trials. If they are invited to follow and understand their culture and try to reflect on that culture, the teenager in developing his career is not uprooted from his cultural roots. Collective and religious culture; career culture that emphasizes sakinah family, harmony with neighbors, and worth of worship.

\section{Conclusion}

The "Assir Jailani" or "Sîr" activity is selamatan held by someone, if he is given a gift in his career or so that his career continues to grow. For them, the meaning of "Sîr" is an activity to remind again that his career is a means to worship and hope for the pleasure of Allah. Career success, not just success in his self-concept, but also success before God by multiplying worship, alms, lawfully undergoing a career, and always hoping for God's pleasure

In the context of "Selamatan Sîr", a person considered successful in a career is not just feeling collective prosperity and happiness with his family, friends, or neighbors, but that career must also be in line with God's pleasure. Therefore, in carrying out a career, do not harm other people and must be taken in a halal way, so that they will get God's approval. Thus, the scholars of the past have succeeded in changing the paradigm of thinking of the community that a career is not just a matter of quality and personal abilities of the person in work, not just he is able to maintain good relations with family, neighbors, and colleagues. Career is also a matter of hoping for God's pleasure. Therefore, they are required to work well, collaborate with colleagues, interact with neighbors, and also worship God. Past scholars have succeeded in Islamizing through salvation and giving meaning that is quite deep and valuable.

\section{References}

[1] L. S. Alvin and R. V. E. .A. Athanasou, International Handbook of Career Guidance. Springe, 2008.

[2] Centre for Strategic and International Studies, Ada Apa Dengan Milenial? Orientasi Sosial, Ekonomi, dan Politik. Jakarta: CSIS, 2017.

[3] S. Arifin, Sang Pelopor: Kisah Tiga Kiai dalam Mengelola Bekas Bajingan. Surabaya: Pena Salsabila, 2014.

[4] S. Arifin, At-Tawazun: Psikologi dan Konseling Berbasis Pesantren untuk Membentuk Karakter Khaira Ummah. Malang: Literasi Nusantara, 2020. 
[5] S. Arifin, "Menjadi Warga Negara Khaira Ummah Dengan Hidup Sehat Tanpa Korupsi," J. Konseling Reli., vol. 9, no. 1, pp. 39-60, 2018.

[6] S. Hadi, "Tarekat Kadiran pada Masyarakat Kadiara Timur Pragaan Sumenep: Sejarah, Keunikan, dan Makna Simboliknya," Nuansa, vol. 10, no. 1, pp. 1-20,2013.

[7] Norhasan, "Pola Ritual dan Makna Simbolis Tradisi Kadiran," Teosofi, vol. 2, no. 1, pp. 50-66, 2012.

[8] N. Istiqomah, Muslihati, and A. Atmoko, "Work Value dalam Serat Wedhatama dan Implikasinya terhadap Bimbingan Karier Berbasis Budaya Jawa," J. Pendidik., vol. 2, no. 6, pp. 806-811, 2017.

[9] Muslihati, "Nilai-nilai Psychological Well-Being dalam Budaya Madura dan Kontribusinya Pada Pengembangan Kesiapan Karier Remaja Menghadapi Bonus Demografi,” J. Stud. Sos., vol. 2, no. 1, pp. 50-66, 2014.

[10] P. J. Spradley, Participant Observation. New York,: Holt Rinehart and Winston, 1980.

[11] A. Mappiare, Tipe-Tipe Metode Riset Kualitatif: untuk Eksplanasi Sosial Budaya dan Bimbingan dan Konseling. Malang: Elang Emas, 2013.

[12] Fatchan, Metode Kualitatif Beserta Contoh Proposal Skripsi, Tesis, dan Desertasi. Surabaya: Jenggala Pustaka Utama, 2011.

[13] S. Arifin and A. Zaini, "Dakwah Inklusif di Kalangan Bajingan : Membedah Komitmen Bekas Bajingan dalam Membangun Peradaban Perspektif Psikologi Sosial,” J. Dakwah, vol. XIX, no. 1, pp. 29-50, 2018.

[14] U. Kim, Indigenous and Cultural Psyichology. New York,: Springer Science, 2006.

[15] M. . Woodward, Islam Jawa: Kesalehan Normatif Versus Kebatinan. Yogyakarta: LKIS, 2006.

[16] S. A. Hasan, Kharima Kiai As'ad di Mata Umat. Yogyakarta: LKIS, 2003.

[17] A. A. Ibrahimy and S. Arifin, Kiai Fawaid As'ad: Kepribadian, Pemikiran, dan Perilaku Politik. Situbondo: Tanwirul Afkar, 2018.

[18] S. Arifin and Wisri, "Politik Kebangsaan Kiai Pesantren (Studi Kepribadian dan Perilaku Politik K.H.R. Ach. Fawaid As'ad Situbondo)," in 3rd Annual Conference For Muslim Scholars (AnCoMS), 2019, pp. 343-353.

[19] A. F. As'ad, Al-Adzkârul Yaumiyah. Situbondo: Salafiyah Syafi'iyah Sukorejo, 1995.

[20] Sukaryo, Jâmi'ud Da'awât. Situbondo: Salafiyah Syafi'iyah Sukorejo, 1996.

[21] Quraish Shihab, Tafsir Al-Mishbah: Pesan, Kesan, dan Keserasian al-Qur'an. Jakarta: Lentera Hati, 2012.

[22] S. Arifin, "Hidup Berkat dan Sehat: Kearifan Kiai Pesantren dalam Memperbaiki Kesehatan Jiwa Masyarakat dalam Kitab Al-Adzkar Al-Yaumiyyah," in Tradisi dan Kebudayaan Nusantara, S. Al Qutuby and I. Y. M. Lattu, Eds. Semarang: Lembaga Studi Sosial dan Agama (eLSA) Press, 2019, pp. 58-83.

[23] A. A. Ibrahimy and S. Arifin, Risalah Hati: Trilogi Biografi Nyai Zainiyah As'ad. Situbondo: Tanwirul Afkar, 2019.

[24] S. Arifin and A. Zaini, "Dakwah Pemberdayaan Berwawasan Lingkungan Untuk Daerah Konflik di Pinggiran Hutan Baluran Banyuputih Situbondo," As-sidanah, vol. 1, no. 1, pp. 1-18, 2019.

[25] S. Arifin, Wejangan Kiai As'ad dan Kiai Fawaid. Surabaya: Pena Salsabila, 2014.

[26] S. Arifin and A. Zaini, "Decision of Implementing Uzlah and Gerbat Techniques in Islamic Boarding School as Preparedness Response for Covid-19 Pandemic," Unnes J. Public Heal., vol. 9, no. 2, 2020.

[27] S. Arifin, "Ta'zir dalam Pendidikan Pesantren (Kajian Teknik Pengubahan Tingkah Laku Perspektif Konseling)," in 1st Annual Conference for Muslim Scholars, 2017, no. 110, pp. 812-823.

[28] A. S. Arifin, Risalah At-Tadzkirah fi 'Uqdin Nihah. Situbondo: Pondok Pesantren Sukorejo, 1975.

[29] D. E. Super, "A Lfe-Span, Life-Space Approach to Career Development," in Career Choice and Development: Applying Contemporary Theories to Practice, D. Brown and L. Brooks, Eds. San Francisco: Jossey-Bass, 1990.

[30] Shelley E. Taylor, L. A. Peplau, and D. O. Sears, Social Psychology. New Jersey: Pearson, 2003.

[31] S. Arifin and A. Zaini, "Transformative Da'wah Through Counseling for the Career Development of Coffee Farmer Groups in the Tourism Village Banyuwangi," J. Konseling Reli., vol. 10, no. 2, pp. 215-231, 2019.

[32] S. Arifin, "Pengembangan Self-Concept Khaira Ummah Santri Perempuan Menyongsong Era Society 5.0 Perspektif Pengembangan Karier," Hisbah J. Bimbing. Konseling dan Dakwah Islam, vol. 17, no. 1, pp. 33-60, 2020.

[33] Santrock. J.W, Remaja. Jakarta: Erlangga, 2007. 